УДК 378.124

\title{
ОСОБИСТІСНІ ЯКОСТІ ТА СОЩАЛЬНІ ПРІОРИТЕТИ ВИКЛАДАЧІВ
}

\author{
Г. В. Дзяк, Т. О. Перцева, Л. Ю. Науменко, Г. В. Горбунова
}

Держсавний заклад “Дніпропетровська медична академія Міністерства охорони здоров’я Украӥни”

\section{PERSONALITIES AND SOCIAL PRIORITIES OF TEACHERS}

\author{
H. V. Dzyak, T. O. Pertseva, L. Yu. Naumenko, H. V. Horbunova \\ State Establishment "Dnipropetrovsk Medical Academy of Ministry of Public Health of Ukraine"
}

\begin{abstract}
У статті звернено увагу не тільки на створення умов щодо формування практичних навичок у студентів, але і до особистості викладача як головної фігури навчального процесу.
\end{abstract}

The article is dedicated not only to the conditions creation for the formation of practical skills in students, but also to the teacher individuality as the main figure of the educational process.

Вступ. У процесі реформування вищої медичної освіти в Україні основна увага приділяється створенню матеріально-технічної бази, оптимізації навчального процесу та методичного забезпечення, але недостатня увага приділяється викладачу як головній фігурі у вирішенні поставлених перед вищою школою завдань.

Основна частина. Вища освіта - системний результат, створений працею розробників навчальних планів і програм, який поєднується з працею авторів підручників і навчальних посібників, з спільною працею самого студента і багатьох викладачів, які керують його навчанням і проводять різноманітні заняття. Якість підготовки фахівців безпосередньо залежить від умов навчання, від якісного професорсько-викладацького складу, від матеріально-технічної бази ВМНЗ, від формування відповідальності студентів за якість освіти, яку вони отримують, тощо. Клінічні кафедри академії мають достатню навчальну базу і обладнані відповідно до сучасних вимог, що дозволяе формувати практичні навички студентів “біля ліжка хворого.” Протягом останнього року академія придбала для поповнення існуючої бази клінічних кафедр для відпрацювання практичних навичок студентів медичних факультетів значну кількість комп'ютерної техніки, фантомів та тренажерів. Серед них: “Набори для сестринської практики”, "Моделі людини (жінки, чоловіка) по догляду за пацієнтом”, “Тренажери для внутрішньовенних ін'єкцій”, “Модель легень з гортанню”, “Модель учбова для СДР немовлят, $з$ контролем”, “Модель невідкладна допомога при пневмотораксі”, “Манекени людини для навчання і проведення реанімаційних заходів де люкс ", “Модель для інтубації”, “Торси реанімаційні, з блоком контролю", "Моделі жіночого таза 3 плодом" тощо. В академії створена система формування вмінь та практичних навичок відповідно до вимог державного стандарту вищої освіти на заняттях “біля ліжка хворого”, удосконалюється навчально-методичне забезпечення та оптимізація самостійної аудиторної та позааудиторної роботи студентів; впроваджена система внутрішньовузівського незалежного від кафедр ректорського тестового контролю рівня знань, як першого етапу підсумкового модульного контролю, як складової частини комплексної оцінки практики студентів тощо. Удосконаленню практичної підготовки студентів сприяє оптимізація умов для їх безпосередньої роботи “біля ліжка хворого”. Придбана академією комплексна навчаюча система 3 тренажерами "Online Version of Medical Examination Skills Training System” сприяє запровадженню у навчальний процес новітніх технологій. Досягнення академії в галузі освіти були відзначені золотою медаллю на Третій міжнародній виставці “Сучасні заклади освіти - 2012”- - номінації “Діяльність вищого навчального закладу з підвищення якості підготовки фахівців".

Академія постійно проводить певні заходи щодо оновлення колективів кафедр, створення умов щодо формування наступництва поколінь викладачів, розповсюдження педагогічного досвіду з метою підвищення якості підготовки майбутніх лікарів. Сьогодні в академії кожен п'ятий педагог відноситься до категорії “молодий викладач”. Проведення методич-

(ㄷ Г. В. Дзяк, Т. О. Перцева, Л. Ю. Науменко, Г. В. Горбунова 
них семінарів для молодих викладачів було заплановано і до програми були включені тематичні пропозиції кафедр, які вони внесли в звітах за підсумками навчального року для заслуховування на цих семінарах. Були заслухані доповіді “Проблеми підготовки сучасного викладача вищої школи”, “Психологічні фактори успішної діяльності викладача вищої школи", “Психологічний портрет викладача медичної академіі”, “Питання профілактики алкоголізму та наркоманії в роботі викладача медичного вузу”, “Психологічні та морально-етичні принципи формування особистості студента-медика" тощо. Усім присутнім викладачам завідувачем лабораторії психофізіологічних досліджень академії були запропоновані методики тестування для визначення типу нервової системи, навченості та лідерських якостей. Кожному викладачу надана можливість отримати індивідуальну консультацію в лабораторії психофізіологічних досліджень академії за станом свого психологічного портрета. В академії існує система “'зворотного зв' язку” і щорічно проводяться анкетування студентів, випускників, викладачів. В цьому році особливу увагу ми приділили “молодим" викладачам, які мають педагогічний стаж 4 роки. За спеціально створеною анкетою було опитано 95 осіб. Розподіл "молодих" викладачів за віком показує, що 12,63 \% складає група віком до 25 років; 25,26 \% - віком від 26 до 29 років, а $62,11 \%$ викладачів мають вік 30 років і більше. За статтю викладачі розподілилися так: 62,1 \% жінки, 37,9\% - чоловіки. За сімейним станом, 37,9 \% жінок та $20 \%$ чоловіків мають сім'ю. $61,1 \%$ опитаних забезпечені особистим житлом, 22, 1 \% живуть 3 батьками, 11,6\% - на орендованих квартирах, а 5,3 \% - мають місце в гуртожитках. У 42,11 \% опитаних дисертація захищена, у 27,37 \% - на стадії закінчення, а кожен третій $(29,48$ \%) 3 опитаних ведуть пошук теми дисертації. Серед тих, хто захистив дисертацію, 57,5 \% жінок та 42,5 \% чоловіків. Серед них $5 \%$ складає група віком до 25 років, 22,5 \% - у віці 26-29 років, а 72,5 \% - ті, кому 30 років і більше. Захист дисертації не дає миттєвого підвищення рівня викладацької роботи. Крім знань дисципліни необхідні навички та досвід викладача. На запитання анкети “Що Вам подобається у Вашій роботі?” 73,5 \% жінок та 53,13 \% чоловіків відповіли, що “Подобається педагогічна робота". 63,16 \% усіх опитаних підкреслили “Можливість підвищувати професіоналізм”, 45,2% - "Можливість спілкуватися 3 молоддю". Кожного четвертого приваблює “Велика відпустка”. Далі йдуть відповіді “Надійна гарантія моєї занятості" (21,2 \% опитаних), “Хороші умови праці” (14,74 \%),
“Не дуже жорсткий графік роботи” (9,47 \%). Опитані добре розуміють, “якими якостями повинен володіти сучасний викладач": бути професіоналом у своїй спеціальності $(83,16$ \%); виступати перед студентами як джерело певного досвіду, до якого студент завжди може звернутися за допомогою (71,58 \%); ставитися до студентів з повагою та бути вимогливим до них (75,59 \%); бути урівноваженим, проявляти витримку та самовладання $(62,11 \%)$ тощо. У 93,68 \% молодих викладачів виконувана на кафедрі робота відповідає спеціальності по диплому. На запитання анкети "Чому Ви обрали ДЗ “ДМА”?" $65,63 \%$ жінок та 57,14 \% чоловіків підкреслили відповідь “Можливість реалізувати своїзнання, досвід та здібності". Другий ранг займає відповідь "Можливість займатися наукою та видавати свої труди" (47,37 \% опитаних). Кожен третій підкреслив "Висока престижність академї”. Для кожного четвертого - це "Можливість просунутися по службі, зробити кар'єру”, а також “Набути досвід, знання та зв' язки для праці в інших сферах”. Для певної частини опитаних - це "Стабільна видача зарплатні" та “Близькість від місця проживання”. Аналіз відповідей респондентів на питання анкети “До чого Ви в першу чергу прагнули, коли погоджувалися на викладання в академії?" Найбільш значимими були відповіді “'Знайти роботу з наявної у мене спеціальності” (46,32 \%) та “Знайти роботу саме в академіі” (41,05 \% опитаних). Кожна четверта жінка $(25,4 \%)$ i лише 9,38 \% чоловіків прагнули “Знайти роботу у сфері освіти”. 83,16 \% опитаних підкреслили, що “потребують підвищення кваліфікації, 5,26 \% відповіли “ні", а 10,47 \% вказали "важко відповісти". Лише 46,32 \% опитаних “повністю задоволені” можливостями підвищення кваліфікації, які надаються на кафедpi”. 44,21 \% опитаних задоволені “частково”, 4, 16 \% підкреслили, що “не задоволені”, 5,25 \% написали “важко відповісти”. На запитання “Яку форму підвищення кваліфікації Ви вважаєте найбільш прийнятною?” відповіді розподілилися у такій послідовності: “курси підвищення кваліфікації в інших ВНЗ”' (60% опитаних); “відвідування лекцій, практичних занять на кафедрі” (57,8 \%); “відвідування постійно діючих методичних семінарів у ВНЗ” (37,9 \%); “участь у роботі семінарів, конференцій” (38,9\%) тощо.

Викладачами внесена значна кількість пропозицій щодо удосконалення їх підготовки до професійної діяльності та їі удосконалення.

В цілому за результатами анкетування можливо зробити висновки, що нова зміна викладачів: бажає бути професіоналами, краще володіти новими тех- 
нологіями навчання та контролю успішності засвоєння студентами нових знань, вмінь та навичок; краще володіти комп'ютерною технікою та активно використовувати іiі в навчальному процесі, краще володіти англійською мовою, постійно підвищувати свою кваліфікацію, опанувати досвідом інших навчальних закладів, як в Україні, так і за кордоном. Разом $з$ тим на питання "Чи вважаєте Ви себе со-

\section{Лiтература}

1. Впровадження кредитно-модульної системи організації навчального процесу у ВМ(Ф)НЗ України : результати, проблеми та перспективи : матеріали Всеукраїнської навчально-методичної конференції $з$ міжнародною участю. - Тернопіль : ТДМУ, 2010. -494 с. ціально захищеними?” - лише 16,84 \% викладачів відповіли “так”, 26,32 \% відповіли “скоріше так, аніж ні”; 26,32 \% відповіли “ні”, кожен п'ятий (21,05 \%) “скоріше ні, аніж так", а 9,47 \% відповіли "важко відповісти". Тому молоді викладачі висловлюють надію на підвищення зарплати, збільшення соціальної захищеності молодих сімей, допомогу у забезпеченні житлом.

2. Нові напрямки впровадження кредитно-модульної системи організації навчального процесу у ВМ(Ф)НЗ України III-IV рівнів акредитації: матеріали Всеукраїнської наукової навчально-методичної конференції (Тернопіль, 12 13 травня 2011). - Тернопіль : ТДМУ, 2011.-568 с. 